\title{
The present lichen flora of the city of Petrozavodsk
}

\author{
Viktoria N. Tarasova ${ }^{1}$, Angella V. Sonina ${ }^{1}$, Vera I. Androsova ${ }^{1} \&$ Teuvo Ahti $^{2}$ \\ ${ }^{1}$ Department of Botany and Plant Physiology, Petrozavodsk State University, Lenin av., 33, 185910 Petrozavodsk, Russia. \\ ${ }^{2}$ Botanical Museum, Finnish Museum of Natural History, P.O. Box 7, FI-00014 University of Helsinki, Finland. \\ E-mails: vika18@sampo.ru, angella_sonina@mail.ru,vera28@karelia.ru, teuvo.ahti@helsinki.fi
}

\begin{abstract}
The present study reports 228 species of lichens and lichenicolous or non-lichenized saprobic fungi in Petrozavodsk (Republic of Karelia, Russia). Seven lichen species of Karelian Red Data Book are recorded. Three species are reported for the first time for Karelia: Arthonia fusca (A. Massal.) Hepp, Hypocenomyce caradocensis (Leight. ex Nyl.) P. James \& Gotth. Schneid., and Pycnora sorophora (Vain.) Hafellner. 47 species are reported as new to Karelia olonetsensis, 7 species as new to Karelia onegensis (Fadeeva et al., 2007).
\end{abstract}

\section{INTRODUCTION}

The first records of lichens of Petrozavodsk date back to the middle of the 19th century. The first collections of lichens were made by a number of Finnish botanists in the period of 1850 to 1898: Th. Simming, A. Kullhem, M. Brenner, W. Nylander, J. P. Norrlin, A. K. Cajander, J. I. Lindroth (Liro). The first sets of their specimens are now preserved in Helsinki $(\mathrm{H})$. Some data were also published by them (e.g., Nylander, 1866; Norrlin, 1876). A local early collector was A. K. Günther, a pharmacist in Petrozavodsk, and many of his collections are also in Helsinki. During the Finnish occupation of Petrozavodsk in 1941-44, in the World War II, a number of additional collections were made by the Finnish botanists A. Koskinen, M. Laurila, L. Fagerström, and V. Räsänen. Their specimens are also preserved in H. Some of their records were also published (e.g., Fagerström, 1945; Koskinen, 1961). In total,

155 lichen species were reported for Petrozavodsk before 1945 . Only 114 species of them were found in recent surveys (Tarasova et al., 2012). The early papers were analyzed in the Karelian lichen checklists by Fadeeva et al. (1997, 2007), but Petrozavodsk is not usually specifically cited. It should be noted that in their botanical province system Petrozavodsk is mainly included in Karelia olonetsensis (Kol), while its northern parts (and particularly the present town district Solomennoe, Botanical Garden and Nature Reserve Zaozersky), were included in Karelia onegensis (Kon). In some literature and on labels Petrozavodsk has been occasionally incorrectly totally included in Karelia onegensis.
The recent studies of lichen diversity and distribution under urban conditions in Petrozavodsk started in the1990s (Sonina, Sysoyeva, 1997; Kuzmina, Sonina, 2002; Tarasova, Evseeva, 2006; Tarasova, Sonina, 2006; Tarasova et al., 2007; Sonina et al., 2008; Tarasova et al., 2008; Tarasova et al., 2010). This paper summarizes the studies of lichen species diversity in Petrozavodsk in 1995-2012. Our comprehensive inventory shows that the species composition of lichens in this city has clearly changed during the 150 year period (Tarasova at al., 2012). The main reasons are expansion of the town area, as well as increasing urban effects on lichens.

\section{Study area}

Petrozavodsk is the capital and the biggest town of the Republic of Karelia. It is situated in the North-West of Russian Federation (Fig. 1). The town is located on the banks of Petrozavodsk Bay of Lake Onega (about $61^{\circ} 50^{\prime} \mathrm{N}, 34^{\circ} 20^{\prime} \mathrm{E}$ ). It was established around an arms factory, constructed near the river Lososinka in 1703 by Peter the Great.

Petrozavodsk has a population of 234000 (2010) and the town area is $135 \mathrm{sq} . \mathrm{km}$. Nowadays there are machine-building, metal working, wood working, constructing, food, light and typographic industries in Petrozavodsk.

Petrozavodsk stretches for nearly $25 \mathrm{~km}$ along the Petrozavodsk Bay of Lake Onega. The relief of the town area was formed by glacial and glaciofluvial actions on soil and bedrock surface and is characterized by considerable dissection. Absolute heights vary from 33 (the level of Lake 


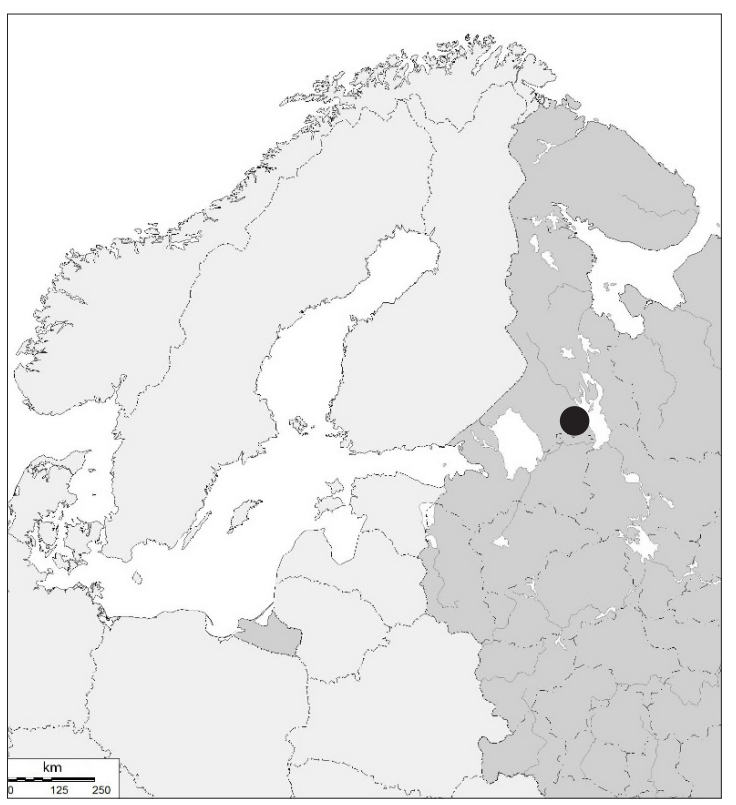

Fig. 1. Location of Petrozavodsk.

Onega) to $145 \mathrm{~m}$ above the sea level (Lukashov, 2003). Geologically the territory of the town is located within the Precambrian Baltic Shield. Within the territory of the city there are two rivers, Lososinka and Neglinka, and other streams, draining to Lake Onega. Bare rock outcrops are common in the area (Lukashov, 2003).

The climate of the area is moderately continental, with some oceanic features. The winter is prolonged and relatively mild, the summer is short and cool. The weather is changeable due to frequent western cyclones. The duration of a frost-free period is $120-130$ days. The mean annual precipitation is $550-600 \mathrm{~mm}$. The annual average temperature is from 0 to $+3{ }^{\circ} \mathrm{C}$. The mean monthly temperature varies from $-11^{\circ} \mathrm{C}$ in January to $+15.6{ }^{\circ} \mathrm{C}$ in July.

Petrozavodsk is located in the middle boreal subzone (southern boreal according to Finnish zonal system), where coniferous forests mainly dominate. A characteristic feature of the town is that there is a historically established dense central city of large stone buildings and residential sections with surrounding heavily urban landscapes, and large areas of natural vegetation preserved within the town limits, mainly located between the separate suburbs and along the town borders. However, the forests have decreased substantially for the last 150 years and now occupy about 400 hectares. Within the town limits there are two protected areas: Botanical Garden of Petrozavodsk State University (PetrSU) and Nature Reserve Zaozersky.

In comparison with other industrial Karelian towns (Kondopoga, Segezha, Kostomuksha, Nadvoitsy), Petrozavodsk is characterized by lower level of pollution. The main pollutants are carbon dioxide and nitrogen, and the main source of pollution is automobile traffic which has increased rapidly in recent times (State report..., 2012).

\section{MATERIAL AND METHODS}

The main part of the material was collected in 1992-2012. The cited specimens are deposited in the Herbarium of Petrozavodsk State University (PZV). Some specimens were studied in the lichen herbaria of Botanical Museum of University of Helsinki (H). TLC technique was not used in species determination and therefore "cf." was added to the identification of some species.

Five habitat types are distinguished within the town area according to different levels of human impact:

1. Residential area-different types of buildings, yards, man-made constructions, downtown and bedroom quarters, shores of Lake Onega, banks of the rivers Lososinka and Neglinka.

2. Parklands - artificial plantations: parks, squares, alleys. The oldest town parks are 150-200 years old.

3. Natural forests - fragments of natural pine and spruce forests survived in urban development.

4. Botanical Garden of PetrSU - founded in 1951 on the northeastern shore of Petrozavodsk Bay of Lake Onega on south slope of a relic, ancient volcano. The territory of the Botanical Garden is 367 ha. This figure includes an arboretum and natural forest areas with predominance of spruce and pine forests.

5. Nature Reserve (zakaznik) Zaozersky - located on the northwestern shore of Lake Onega. The reserve was founded in 1991. It occupies about 400 ha within the town limits (total extent 2710 ha). The area is mostly covered with spruce and pine forests with fragments of secondary deciduous communities. 


\section{LIST OF SPECIES}

The nomenclature of the cited taxa mainly follows the online version of the checklist by Santesson et al. (2004) or in some cases Urbanavichus (2010). Annotations are given about the substrate and habitat types of recorded species. Frequency is stated only for the species of Karelian Red Data Book and new species for Karelia using the following estimation classes: very rare (1 find), rare (2-10 finds), scattered (more than 10 finds).

Abbreviations and symbols: \# - lichenicolous fungi; + - non-lichenized fungi; ! - species of Karelian Red Data Book (2007); RA - residential area; PR - parklands; NFA - natural forest area; BG - Botanical Garden of PetrSU; NR - Nature Reserve (zakaznik) Zaozersky; Kol! - new to Karelia olonetsensis; Kon! - new to Karelia onegensis (Fadeeva et al., 2007).

ACAROSPORA FUSCATA (Schrad.) Th. Fr. - on rocks and boulders on the shores of Onega Lake. BG.

ACAROSPORA VERONEnSIS A. Massal. - on boulders and granite parapet of the embankment on the shore of Onega Lake, on boulders on the banks of the Lososinka River. RA, BG. Kon! Kol!

Alectoria sarmentosa (Ach.) Ach. - on trunks and branches, mainly on old trees of Pinus sylvestris and Picea abies. BG.

Amandinea Punctata (Hoffm.) Coppins \& Scheid. - on trunks of Populus tremula, on worked timber. RA, NFA, BG, NR. Kol!

! ANAPTYCHIA CILIARIS (L.) Körb. ex A. Massal. - on trunk of Populus tremula. NFA. Rare.

ARctoparmelia CENTRifuga (L.) Hale - on rocks and boulders. BG.

ARTHONIA DidyMA Körb. - on trunks of Picea abies and Populus tremula. NFA, NR. Kol!ARTHONIA FUSCA (A. Massal.) Hepp - on slate roofs. RA. Very rare. Kol!

Aspicilia aquatica (Fr.) Körb. - on rocks and boulders on the shores of Onega Lake, on the banks of the Lososinka and Neglinka Rivers. RA, BG.

AsPiCILIA CAESIOCINEREA (Nyl. ex Malbr.) Arnold on boulders on the shores of Onega Lake, on the banks of the Lososinka and Neglinka Rivers. RA.

ASPICILIA CINEREA (L.) Körb. - on boulders on shore of the Onega Lake, on the bank of Lososinka River. BG, RA.
Aspicilia moenium (Vain.) G. Thor \& Timdal - on slate roofs, on sand. RA. Kol!BACIDIA CIRCUMSPECTA (Nyl. ex Vain.) Malme - on trunks of Populus tremula. NR.

BACIDIA SUBincomPTA (Nyl.) Arnold - on trunks of Populus tremula. NFA.

BACIDINA INUNDATA (Fr.) Vězda - on boulders on the shores of Onega Lake, on the banks of the Lososinka River. RA.

BAEOMYCES RUfus (Huds.) Rebent. - on sandy soil, on primary soil over boulders. BG, NR.

Bellemerea alpina (Sommerf.) Clauzade \& Cl. Roux - on boulders on the shores of Onega Lake. BG. Kon!

Bellemerea Cinereorufescens (Ach.) Clauzade \& Roux - on boulders on the shores of Onega Lake. BG.

BiATORA HELVOla Körb ex Hellb. - on trunks of Sorbus aucuparia. NFA. Kol!

BiATORA OCELLIFORMis (Nyl.) Arnold - on trunks of Sorbus aucuparia. NFA. Kol!

BRYORIA CAPILLARIS (Ach.) Brodo \& D. Hawksw. on branches of various trees. RA, PR, NFA, BG, NR.

Bryoria furcellata (Fr.) Brodo \& D. Hawksw. - on trunks of various trees, especially on coniferous trees. RA, PR, NFA, BG, NR.

BRYoria FUSCESCENS (Gyeln.) Brodo \& D. Hawksw. - on trunks of Pinus sylvestris, Picea abies and Betula sp. RA, PR, NFA, BG, NR.

! BRYORIA NADVORNIKIANA (Gyeln.) Brodo \& D. Hawksw. - on branches of Picea abies. NFA, NR. Scattered. Kol!

Bryoria subcana (Nyl. ex Stizenb.) Brodo \& D. Hawksw. - on trunk of Salix caprea. BG. Kon!

Buellia Disciformis (Fr.) Mudd - on trunks of Populus tremula and Alnus incana. RA, NFA.

Buellia GRISEOVIRENS (Turner \& Borrer ex Sm.) Almb. - on trunks of Alnus incana and Sorbus aucuparia. NFA, BG, NR.

CAlicium ADAEQUatum Nyl. - on trunks of Alnus glutinosa. NFA. Kol!

Calicium Denigratum (Vain.) Tibell - on barkless snags. RA, NFA, NR. Kol!

CALICIUM GLAUCELLUM Ach. - on barkless snags of Pinus sylvestris. NFA, NR.

Calicium Parvum Tibell - on trunks of Picea abies and Pinus sylvestris. NFA.

CAloplaca Cerina (Hedw.) Th. Fr. - on trunks of Populus tremula. RA, PR, NFA, NR.

CAloplaca ferruginea (Huds.) Th. Fr. - on trunks of Populus tremula, Picea abies, Betula sp., 
on timber, on fences, on concrete. RA, PR, NFA, NR. Kol!

Caloplaca flavorubescens (Huds.) J.R. Laundon - on trunks of Populus tremula. NFA, NR. Kol!

Caloplaca holocarpa (Hoffm.) A.E. Wade - on timber, on rocks on shores of Onega Lake, on the banks of the Lososinka of River. RA.

CALOPLACA PYRACEA (Ach.) Th. Fr. - on trunks of Alnus incana and Populus sp., on slate roofs. RA.

CANDElariella aurella (Hoffm.) Zahlbr. - on boulders on the shores of Onega Lake, on slate roofs, timber. RA. Kol!

Candelariella vitellina (Hoffm.) Müll. Arg. - on trunks of Populus sp., on boulders on the shores of Onega Lake, on the banks of the Lososinka River. BG. RA.

CAndelariella Xanthostigma (Ach.) Lettau - on timber. RA.

Cetraria ericetorum Opiz - on soil, on mosscovered boulders and rocks. BG, NR.

Cetraria islandica (L.) Ach. - on soil, on mosscovered rocks, on trunk bases of coniferous trees. NFA, BG, NR.

CETRARIA ODONTElla (Ach.) Ach. - on primary soil over rocks. BG.

Cetraria sePincola (Ehrh.) Ach. - on trunks and branches of deciduous and coniferous trees. PR, NFA, BG, NR.

Chaenotheca chrysocephala (Turner ex Ach.) Th. Fr. - on trunks of Picea abies and Pinus sylvestris. NFA, BG, NR.

Chaenotheca ferruginea (Turner ex Sm.) Mig. on trunks of coniferous trees, on deciduous snags. NFA, BG, NR. Kol!

ChaenotheCA Furfuracea (L.) Tibell - on upended roots of Picea abies. NFA, NR.

ChAENOTHECA TRICHIALis (Ach.) Th. Fr. - on trunks of Pinus sylvestris, Juniperus communis and Betula sp. NFA, BG, NR.

\# CHAENotheCopsis SAVonica (Räsänen) Tibell - on barkless snags of Pinus sylvestris. NFA. Kol!

CHRYSOTHRIX CANDELARIS (L.) J.R. Laundon - on trunks of Populus tremula. NFA. Kol!

CHRYSOTHRIX CHLORINA (Ach.) J.R. Laundon - on rocks. BG.

Cladonia AmaURocraea (Flörke) Schaer. - on primary soil over boulders. NFA.

Cladonia arbuscula ssp. sQuarRosa (Wallr.) Ruoss - on moss-covered rocks, on primary soil over boulders. NFA, BG, NR.
Cladonia arbuscula ssp. mitis (Sandst.) Ruoss on moss-covered rocks, on primary soil over boulders. NFA, BG, NR.

Cladonia Bacilliformis (Nyl.) Sarnth. - on trunk bases of Pinus sylvestris, Betula sp., on moss-covered stumps. NFA, BG, NR.

Cladonia Borealis S. Stenroos - on primary soil over boulders. BG.

Cladonia Botrytes (K.G. Hagen) Willd. - on trunk bases, on decaying wood, on stumps. NFA, $\mathrm{BG}, \mathrm{NR}$.

Cladonia Cenotea (Ach.) Schaer. - on soil, on trunk bases of various trees, on decaying wood, on moss-covered stumps, on primary soil over boulders NFA, BG, NR.

Cladonia Chlorophata (Flörke ex Sommerf.) Spreng. s. lat. - on moss-covered boulders, on soil, on decaying wood, on trunk bases of various trees. NFA, BG, NR.

Cladonia CONIOCRAEA (Flörke) Spreng. - on trunk bases of various trees, on decaying wood, on moss-covered stumps, on primary soil over boulders, on soil. NFA, BG, NR.

Cladonia CORNUTA (L.) Hoffm. - on decaying wood, on moss-covered stumps, on primary soil over boulders, on soil. NFA, BG, NR.

Cladonia CRISPATA (Ach.) Flot. - on soil, on decaying wood, on moss-covered stumps, on primary soil over boulders. NFA, BG, NR.

Cladonia deformis (L.) Hoffm. - on trunk bases of various trees, on decaying wood, on moss-covered stumps, on primary soil over boulders, on soil. NFA, BG, NR.

Cladonia digitata (L.) Hoffm. - on trunk bases of various trees, on decaying wood, on mosscovered stumps, on soil. NFA, BG, NR.

Cladonia fimbriata (L.) Fr. - on trunk bases of various trees, on decaying wood, on mosscovered stumps, on soil. NFA, BG, NR.

Cladonia furcata (Huds.) Schrad. - on soil, on moss-covered boulders. NFA, BG, NR.

Cladonia GRACILIS (L.) Willd. ssp. TURBINATA (Ach.) Ahti - on trunk base of Pinus sylvestris, on decaying wood, on moss-covered boulders, on soil. NFA, BG, NR.

Cladonia macilenta Hoffm. - on trunk bases of various trees, on decaying wood. NFA, BG.

Cladonia PHyllophora Hoffm. - on trunk bases of various trees, on moss-covered boulders, on soil. NFA, BG, NR.

Cladonia Pleurota (Flörke) Schaer. - on mosscovered boulders, on soil, on decaying wood. NFA, BG, NR. 
Cladonia PyXidata (L.) Hoffm. - on moss-covered boulders, on decaying stumps. BG.

Cladonia Rangiferina (L.) F.H. Wigg. - on soil, on decaying stumps, on trunk base of Pinus sylvestris, on moss-covered rocks. PR, NFA, $\mathrm{BG}, \mathrm{NR}$.

Cladonia stellaris (Opiz) Pouzar \& Vĕzda - on soil, on trunk bases of various trees, on moss-covered rocks. NFA, BG, NR.

Cladonia subulata (L.) F.H. Wigg. - on trunk bases of various trees, on moss-covered boulders. NFA, BG, NR.

Cladonia SulPhURINA (Michx.) Fr. - on trunk bases of various trees, on soil, on decaying stumps. NFA, BG, NR.

Cladonia turgida Hoffm. - on soil, on mosscovered boulders. BG.

Cladonia uncialis (L.) F.H. Wigg. ssp. uncialison soil, on primary soil over boulders. NFA, BG, NR.

Collema FURfuraceum (Arnold) Du Rietz - on trunks of Populus tremula. NFA.

Collema subnigrescens Degel. - on trunks of Populus tremula. NFA. Kol!

DERMATOCARPON LURIDUM (With.) J.R. Laundon on boulders in the water of the Lososinka River and Onega Lake. NFA.

Dermatocarpon miniatum (L.) W. Mann - on rocks. BG.

Diploschistes mUSCoRUm (Scop.) R. Sant. - on moss-covered rocks. BG.

Diploschistes SCRUPOSUS (Schreb.) Norman - on rocks. BG.

ENDOCARPON PSORODEUM (Nyl.) Blomb. \& Forssell - on rocks on the shores of Onega Lake. BG.

EPHEBE HISPIDUla (Ach.) Horw. - on boulders on the shores of Onega Lake. BG.

EVERNIA MESOMORPHA Nyl. - on trunks of various trees. PR, NFA, BG, NR.

EVERNIA PRUNASTRI (L.) Ach. - on trunks of deciduous trees. PR, NFA, BG, NR.

FuscopanNARIA PRAETERMissa (Nyl.) P.M. Jørg. - on rocks, on moss-covered rocks. BG.

GRAPHIS SCRIPTA (L.) Ach. - on trunks of Alnus incana. NFA.

Hypocenomyce CARAdocensis (Leight. ex Nyl.) P. James \& Gotth. Schneid. - on branches of Picea abies. NR. Very rare. Kon!

HypocenomyCE FRIESII (Ach.) P. James \& Gotth. Schneid. - on trunks of Pinus sylvestris, on burned trunks and stumps of Pinus sylvestris. RA, NFA, BG, NR.
Hypocenomyce scalaris (Ach.) M. Choisy - on burned trunks and trunk bases of Pinus sylvestris. RA, NFA, BG, NR.

HyPOGYMNIA PHYSODES (L.) Nyl. - on trunks and branches of various trees and shrubs, on barkless snags, on timber, on decayng wood, on stones. RA, PR, NFA, BG, NR.

HyPogymia tUbulosa (Schaer.) Hav. - on trunks and branches of various trees. PR, NFA, BG, NR.

IMMERSARIA CUPREOATRA (Nyl.) Calat. \& Rambold - on boulders on the shores of Onega Lake. BG.

Imshaugia ALEURites (Ach.) S.L.F. Meyer - on trunks of Pinus sylvestris, on branches of shrubs, more rarely on trunks of Picea abies. RA, NFA, BG, NR.

JAPEWIA SUBAURIFERA Muhr \& Tønsberg - on trunks of Betula sp. PR, NFA, BG, NR.

LeCANia CYRTElla (Ach.) Th. Fr. - on trunks of Populus tremula. PR. Kol!

LeCANia NAEgeli (Hepp) Diederich \& Van den Boom - on trunks of Populus tremula. PR. Kol!

LeCANORA ALBELlula (Nyl.) Th. Fr. - on trunks of Populus tremula and Fraxinus sp. PR, BG. Kol!

LECANORA ALLOPHANA Nyl. - on trunks of Populus tremula, Larix sp., Betula sp. PR, NFA, NR.

LECANORA CHLAROTERA Nyl. - on trunks of Alnus incana. NFA, NR. Kol!

LECANORA cf. EXPALLENS Ach. - on timber, on fences. RA. Kol!

LECANORA FRUSTUlOSA (Dicks.) Ach. s. lat. - on rocks and boulders on the shores of Onega Lake. BG.

LECANORA HAGENII (Ach.) Ach. - on trunks of Populus $s p$., on timber, on fences. RA.

LECANORA INTRICATA (Ach.) Ach. - on timber, on fences, on rocks and boulders on the shores of Onega Lake, on the banks of the Lososinka and the Neglinka Rivers. RA, BG.

LECANORA MURALIS (Schreb.) Rabenh. - on rocks and boulders on the shores of Onega Lake, on the banks of the Lososinka and the Neglinka Rivers. RA, BG. Kol!

LECANORA POLYTROPA (Hoffm.) Rabenh. - on timber, on fences, on slate roofs, on rocks and boulders on the shores of Onega Lake, on the banks of the Lososinka and the Neglinka Rivers. RA, BG.

LECANORA POPUlicola (DC.) Duby - on trunks of Betula sp., Populus sp. PR. NFA. 
LeCANORA PUlicaris (Pers.) Ach. - on branches, more rarely on trunks of Pinus sylvestris and deciduous trees. NFA, BG, NR.

LECANORA RUPICOLA (L.) Zahlbr. - on rocks. BG.

LECANORA SALIGNA (Schard.) Zahlbr. - on trunks of various trees, on timber, on fences. RA. Kol!

LECANORA SYMMICTA (Ach.) Ach. s. lat. - on trunks of various trees, on timber, on fences. RA, PR, NFA, BG, NR.

LECANORA VARIA (Hoffm.) Ach. - on timber. RA. Kol!

LECIDELLA EuPHOREA (Florke) Hertel - on trunks of Populus tremula. NR.

LEPRARIA INCANA (L.) Ach. s. lat. - on trunks of various trees, on wood of dead trees, on shaded rocks. RA, NFA, BG, NR. Kol!

LEPRARIA cf. DIFFUSA (J.R. Laundon) Kukwa - on rocks, on mosses over rocks. BG.

LEPRARIA MEMBRANACEA (Dicks.) Vain. - on rocks, on mosses over rocks. BG.

LEPTOGIUM SATURNINUM (Dicks.) Nyl. - on trunks of Populus tremula. NFA, NR.

! LePTOGIUM SUbTiLE (Schrad.) Torss. - on trunks of Populus tremula. NFA. Very rare. Kol!

LEPTOGIUM TERETIUSCULUM (Wallr.) Arnold - on trunks of Populus tremula. NFA. Kol!

\# LePTORHAPHIS EPIDERMIDIS (Ach.) Th. Fr. - on trunks of Betula sp. NFA, BG, NR. Kon!

! LOBARIA PULMONARIA (L.) Hoffm. - on trunks of Populus tremula. NFA, NR. Scattered.

LOXOSPORA ELATINA (Ach.) A. Massal. - on trunks of Pinus sylvestris, Picea abies, Betula sp., on stumps. NFA, BG, NR.

Melanelia hepatizon (Ach.) A. Thell - on boulders and rocks. $B G$.

Melanelixia Glabratula (Lamy) Sandler Berlin \& Arup - on trunks of Tilia cordata and Salix caprea. BG.

Melanelixia subargentifera (Nyl.) O. Blanco et al. - on trunks of Populus tremula. RA. Kol!

MelaneliXia subaurifera (Nyl.) O. Blanco et al. on trunks of Populus sp. RA.

Melanohalea EXAsPerata (De Not.) O. Blanco et al. - on trunks of Populus tremula, on boulders on the shores of Onega Lake. PR, BG.

Melanohalea infumata (Nyl.) O. Blanco et al. - on boulders on the shores of Onega Lake. BG.

Melanohalea olivacea (L.) O. Blanco et al. - on branches of Populus tremula, Alnus incana, Padus avium, Betula sp., Salix sp. PR, NFA, $\mathrm{BG}, \mathrm{NR}$.

Melanohalea septentrionalis (Lynge) O. Blanco et al. - on trunks of Tilia cordata. BG.
Micarea melanea (Nyl.) Hedl. - on trunks of Pinus sylvestris, more rarely on branches of Picea abies. NFA, BG, NR. Kol!

+ Microcalicium disseminatum (Ach.) Vain. - on decaying wood. NFA. Kol!

Multiclavula mucida (Pers.) R.H. Petersen - on wood of fallen deciduous trees. NFA.

Mycobilimbia CARNEOALBIDA (Müll. Arg.) S. Ekman \& Printzen - on trunks of Populus tremula. NFA, NR.

Mycobilimbia EPIXANTHOIDEs (Nyl.) Vitik. et al. ex Hafellner \& Türk - on trunks of Populus tremula. NFA, NR. Kol!

MYcOBILIMBIA PILULARIS (Körb.) Hafellner \& Türk on trunks of Alnus glutinosa. NFA. Kol! Kon!

Mycoblastus SANGUiNARIUS (L.) Norman - on trunks of various trees. NFA, BG, NR.

NePHROMA PARILE (Ach.) Ach. - on mosses over soil, on trunk bases of Populus tremula, Tilia cordata, Salix caprea. NFA, BG, NR.

NEPHROMA RESUPINATUM (L.) Ach. - on trunk bases of Populus tremula. NFA.

OCHROLECHIA ALBOFLAVESCENS (Wulfen) Zahlbr. on trunks of Pinus sylvestris. NFA.

OCHROLECHIA cf. ANDROGYNA (Hoffm.) Arnold - on trunks of various trees, on decaying wood. NFA, BG, NR. Kol!

Ochrolechia pallescens (L.) A. Massal. - on trunks of Populus tremula. NFA.

OPEGRAPHA GYROCARPA Flot. - on vertical surface of rocks. BG.

OPHIOPARMA VENTOSA (L.) Norman - on rocks. BG.

PACHYPHIALE FAGICOLA (Hepp) Zwackh - on trunks of Populus tremula. NFA.

PaRmelia omphalodes (L.) Ach. - on rocks. BG.

Parmelia saXatilis (L.) Ach. - on boulders and rocks, on trunks of old trees. BG.

PARMELIA SULCATA Taylor - on trunks of various trees, on decaying wood, on worked timber. RA, PR, NFA, BG, NR.

PARMELIOPSIS AMBIGUA (Wulfen) Nyl. - on trunks of various trees, on barkless snags, on worked timber, on fences. RA, PR, NFA, BG, NR.

PARMELIOPSIS HYPEROPTA (Ach.) Arnold - on trunks of various trees, on barkless snags, on worked timber. RA, PR, NFA, BG, NR.

Peltigera aphthosa (L.) Willd. - on soil, on primary soil over boulders. NFA, BG, NR.

Peltigera canina (L.) Willd. - on moss-covered trunk bases of Populus tremula, on soil, on primary soil over boulders. NFA, BG, NR.

PELTigera Didactyla (With.) J.R. Laundon - on soil. BG. 
Peltigera Leucophlebia (Nyl.) Gyeln. - on sandy soil, on paths, on verges of forest roads. NFA, BG, NR.

Peltigera malacea (Ach.) Funck - on soil, on primary soil over boulders. NFA, BG.

Peltigera NECKeri Hepp ex Müll. Arg. - on mosscovered fallen trunks of Populus tremula. NFA. Kol!

Peltigera occidentalis (E. Dahl) Kristinsson - on primary soil over rocks. BG.

Peltigera polydactylon (Neck.) Hoffm. - on soil, on primary soil over boulders. BG.

Peltigera PRAETEXTATA (Flörke ex Sommerf.) Zopf - on moss-covered trunk bases of Populus tremula, on soil. NFA, BG, NR.

Peltigera Rufescens (Weiss) Humb. - on soil. NFA, BG.

Pertusaria albescens (Huds.) M. Choisy \& Werner - on trunks of Betula sp., Populus tremula, Picea abies. NFA.

Pertusaria Amara (Ach.) Nyl. - on trunks of Betula sp., Populus tremula, Picea abies. NFA, BG, NR.

PhAEOPHYSCIA CILIATA (Hoffm.) Moberg - on trunks of Populus sp., Populus tremula. PR, NFA.

PhaEOPHYSCIA NigRicans (Flörke) Moberg - on trunks of various deciduous trees. NFA, PR.

PHAEOPHYSCIA ORBICULARIS (Neck.) Moberg - on trunks of various deciduous trees, on timber, on concrete constructions, on slate roofs, on stone walls, on boulders, on rocks. BG, NFA, PR, RA.

PHAEOPHYSCIA SCIASTRA (Ach.) Moberg - on trunks of Populus sp., on boulders on the shores of Onega Lake. RA, BG.

PhLYCTIS ARGENA (Spreng.) Flot. - on trunks of Populus tremula. NFA, NR.

Physcia adscendens (Fr.) H. Olivier - on trunks of Populus sp., Populus tremula. PR, NFA.

Physcia Aipolia (Ehrh. ex Humb.) Fürnr. - on trunks of various deciduous trees, on concrete constructions. RA, PR, NFA, BG, NR.

Physcia Alnophila (Vain.) Lohtander et al. - on trunks of Populus sp. RA.

Physcia CAESia (Hoffm.) Fürnr. - on trunks of Populus sp., on boulders, on slate roofs. RA, BG.

Physcia DUbia (Hoffm.) Lettau - on trunks of Populus sp., on rocks, on slate roofs. BG, NFA, RA.

! Physcia PhaEa (Tuck.) J.W. Thomson - on rocks on the shores of Onega Lake. BG. Rare.
PHYSCIA STELLARIS (L.) Nyl. - on trunks of various deciduous trees. BG, NFA, PR, RA.

Physcia Tenella (Scop.) DC. - on trunks of Populus sp., Populus tremula. PR.

Physconia DETERSA (Nyl.) Poelt - on trunks of Salix caprea. BG.

PhysConia DistoRTA (With.) J.R. Laundon - on trunks of Populus tremula. NFA.

Physconia muscigena (Ach.) Poelt - on mosscovered boulders. BG.

Placynthiella icmalea (Ach.) Coppins \& P. James - on trunks of Populus tremula. NFA, NR.

Placynthiella uliginosa (Schrad.) Coppins \& P. James - on moss-covered fallen trees. NFA. Kol!

Platismatia glauca (L.) W.L. Culb. \& C.F. Culb. - on trunks and branches of various trees, on barkless snags, on timber, on fences, on rocks. RA, PR, NFA, BG, NR.

PoRPIDIA CRUSTULATA (Ach.) Hertel \& Knoph - on rocks and boulders on the shores of Onega Lake, on the banks of the Lososinka River. RA, BG. Kol!

PorPIDIA FLAVICUNDA (Ach.) Gowan - on rocks. BG.

Porpidia tuberculosa (Sm.) Hertel $\&$ Knoph - on rocks. BG.

Protoparmelia Badia (Hoffm.) Hafellner - on rocks, on boulders on the shores of Onega Lake. BG.

PSEUdEVERNIA FURFURACEA (L.) Zopf - on trunks of Pinus sylvestris. NFA, BG, NR.

PYCNORA SOROPHORA (Vain.) Hafellner - on timber. RA. Very rare. Kol!

! RAMALINA DILACERATA (Hoffm.) Hoffm. - on trunks of Salix caprea. BG. Very rare.

Ramalina Farinacea (L.) Ach. - on trunks of Populus tremula, Tilia cordata. NFA, BG.

RAMALINA POLLINARIA (Westr.) Ach. - on trunks of various deciduous trees, on vertical surface of rocks. BG.

RHIZOCARPON BADIOATRUM (Flörke ex Spreng.) Th. Fr. - on rocks and boulders on the shores of Onega Lake, on the banks of the Lososinka and the Neglinka Rivers. RA, BG. Kol!

RHIZOCARPON GEMINATUM Körb. - on rocks and boulders on the shores of Onega Lake. BG.

RHIZOCARPON GEOGRAPHICUM (L.) DC. - on rocks and boulders on the shores of Onega Lake. BG.

RHIZOCARPON HOCHSTETTERI (Körb.) Vain. - on rocks and boulders on the shores of Onega Lake. BG. 
RHIZOCARPON REDUCTUM Th. Fr. - on rocks and boulders on the shores of Onega Lake. BG.

RIMULARIA LIMBORINA Nyl. - on rocks and boulders on the shore of Onega Lake, on the banks of Lososinka River. RA, BG.

RINODINA OLEAE Bagl. - on rocks and boulders on the shore of Onega Lake, on the banks of the Lososinka River. RA, BG. Kol!

Rinodina MiLvina (Wahlenb.) Th. Fr. - on rocks and boulders on the shore of Onega Lake, on the banks of the Lososinka River. RA, BG.

! SClEROPHORA CONIOPHAEA (Norman) Mattsson $\&$ Middelb. - on trunks of Alnus glutinosa. NFA. Very rare. Kol!

Scoliciosporum CHLOROCOCCUM (Graewe ex Stenh.) Vězda - on trunks and branches of Picea abies and Pinus sylvestris. PR, NFA, BG, NR.

SPILONEMA REVERTENS Nyl. - on rocks and boulders on the shores of Onega Lake. BG.

STAUROTHELE FRUSTULENTA Vain. - on flooded rocks and boulders on the shore of Onega Lake, on the banks of Lososinka River and Neglinka River. RA, BG. Kol!

+ Stenocybe pullatula (Ach.) Stein - on trunks of Alnus incana. NFA. Kol!

! STEREOCAULON DACTYLOPHYLLUM Flörke - on primary soil over boulders. BG. Very rare.

Stereocaulon paschale (L.) Hoffm. - on primary soil over boulders. NFA, BG, NR. Kol!

Stereocaulon saxatile H. Magn. - on primary soil over boulders. BG.

STEREOCAULON TOMENTOSUM Fr. - on primary soil over boulders. BG.

Thermutis velutina (Ach.) Flot. - on rocks on the shores of Onega Lake. BG.

TRAPELIA oBTEgens (Th. Fr.) Hertel - on rocks on the shores of Onega Lake. BG. Kon!

Trapeliopsis flexuosa (Fr.) Coppins \& P. James - on trunks of various deciduous trees and Picea abies, on timber. RA, NFA, BG, NR. Kol!

TuCKERMANNIOPSIS CHLOROPHYLLA (Willd.) Hale - on trunks and branches of various trees. RA, NFA, BG, NR.

UMBILICARIA DEUSTA (L.) Baumg. - on rocks and boulders. BG.

UMBILICARIA HYPERBOREA (Ach.) Hoffm. - on rocks and boulders. BG.

UMBILICARIA POLYPHYLLA (L.) Baumg. - on rocks and boulders. BG.

UMBILICARIA TORREFACTA (Lightf.) Schrad. - on rocks and boulders. BG.

USNEA DASYPOGA (Ach.) Nyl. - on trunks and branches of various trees. NFA, BG, NR.
Usnea glabrescens (Nyl. ex Vain.) Vain. - on branches of Picea abies. NFA.

UsNeA HIRTA (L.) F.H. Wigg. - on trunks and branches of various trees. PR, NFA, BG, NR.

USNEA SUBFLORIDANA Stirt. - on trunks and branches of various trees. NFA, BG, NR.

VAHLIELla LeuCophaEA (Vahl) P.M. Jørg. - on vertical surface of rocks. BG.

VERRUCARIA HYDRELA Ach. - on flooded rocks and boulders on the shores of Onega Lake, on the banks of the Lososinka River. RA, BG. Kol!

VULPICIDA PINASTRI (Scop.) J.-E. Mattsson \& M.J. Lai - on trunks and branches of various trees and shrubs, on barkless snags, on timber, on decaying wood, on stones. RA, PR, NFA, BG, NR.

XANTHOPARMELIA CONSPERSA (Ehrh. ex Ach.) Hale on boulders, on primary soil over rocks. BG.

Xanthoparmelia stenophylla (Ach.) Ahti \& D. Hawksw. - on boulders and rocks. BG.

XANTHORIA CANDELARIA (L.) Th. Fr. - on trunks of various deciduous trees. NFA, BG, NR.

Xanthoria PARIETINA (L.) Th. Fr. - on trunks of Populus tremula, on worked timber, on concrete constructions, on slate roofs, on stone walls, on boulders, on rocks. RA, PR, NFA, BG, NR.

XANTHORIA POLYCARPA (Hoffm.) Th. Fr. ex Rieber on worked timber. RA. Kol!

\section{DISCUSSION}

The composition of the lichen flora in Petrozavodsk is quite diverse in comparison with many other cities of Russia. According to the current data on the Russian cities where the lichen flora has been studied, Petrozavodsk comes third after Saint Petersburg (Malysheva, 2005) and Novosibirsk (Svirko, 2006) based on the quantity and diversity of species. However, all the cities have not not been surveyed equally well.. 20\% of all the lichen species known in Karelia were also recorded in Petrozavodsk (Fadeeva et al., 2007). This is caused by several reasons. Firstly, large areas of urban natural forest and nature protected areas contribute to the distribution of typical boreal lichen species. Secondly, occurrence of nemoral tree species in stands of natural communities (Tilia cordata, Alnus glutinosa, etc.), as well as in artificial plantations in city parks and the Botanical Garden (Acer platanoides, Fraxinus excelsior, Populus alba, $P$. laurifolia, P. suaveolens, Quercus robur, Ulmus 
glabra, U. laevis) makes the lichen species composition more southerly than elsewhere in the area. The situation of the city on the large Lake Onega, as well as the presence of two rivers, ralso contribute to higher diversity of lichens. As many as 17 species of lichens (8\%) were found only on boulders and rocks on the shores of Lake Onega and banks of the rivers. Aspicilia aquatica, Dermatocarpon luridum and Verrucaria hydrela are common riverine inhabitants adapted to flooding and are found only on the shores. In addition, Petrozavodsk is also better explored than most of Karelia, although the inventory is not at all complete, especially regarding many sterile crustose lichens and lichenicolous fungi.

Solid crystalline rocks create conditions for the development of a great diversity of epilithic lichens (such as representatives of the genera Aspicilia, Acarospora, Bellemerea, Rhizocarpon, Umbilicaria) and soil lichens (mostly Peltigera and Cladonia) that are found on the thin layer of soil on rocks.

Moreover, there are many anthropogenic substrates in the town area, timber of different constructions being the most densely inhabited by lichens. The following lichens are widely distributed on anthropogenic substrates: Caloplaca holocarpa, Candelariella aurella, C. vitellina, Lecanora hagenii, Phaeophyscia orbicularis. Six species (Arthonia fusca, Candelariella xanthostigma, Lecanora cf. expallens, Lecanora varia, Pycnora sorophora, Xanthoria polycarpa) were found on anthropogenic substrates only.

Arthonia fusca, Hypocenomyce caradocensis and Pycnora sorophora were registered in Karelia for the first time. According to the Karelian lichen checklist by Fadeeva et al. (2007), our survey has yielded 47 species asenew to the biogeographic province Karelia olonetsensis (Kol) and 7 species new to Karelia onegensis (Kon).

The natural forest communities and nature protected within the city greatly contribute to the lichen species diversity in Petrozavodsk. More than $50 \%$ of the total of 152 species was found only in these forests. Moreover, these areas are refugia for several rare and vulnerable species, such as Bryoria subcana, Calicium adaequatum, Collema subnigrescens, Graphis scripta, Hypocenomyce caradocensis, Leptogium teretiusculum, Multiclavula mucida, Nephroma resupinatum, Ochrolechia pallescens, and Usnea glabrescens.

The city parks also provide special lichen diversity. Three species (Lecania cyrtella, L. naegelii, Physcia tenella) were recorded only in parks.

The following eight species of Karelian Red Data Book were recorded in Petrozavodsk: Anaptychia ciliaris), Bryoria nadvornikiana, Leptogium subtile, Lobaria pulmonaria), Physcia phaea, Ramalina dilacerata), Sclerophora coniophaea), and Stereocaulon dactylophyllum). The territory of Petrozavodsk is the second location in the Republic of Karelia where the rare species Collema subnigrescens was registered, on trunks of Populus tremula.

\section{ACKNOWLEDGEMENTS}

We would like to express our gratitude to our colleagues I. N. Urbanavichene, G. P. Urbanavichus, L. V. Gagarina, L. A. Konoreva, and D. E. Himelbrant at Komarov Botanical Institute RAS and Saint Petersburg State University for assistance in species identification. We are also much obliged to Jan Vondrák an, Margarita Fadeeva for consultations, and to the students of Ecological-Biological Faculty of Petrozavodsk State University for assistance in field work. The research was financially supported by the Russian Foundation for Basic Research (grant 09-090755), Development for High School Scientific Resources (project No 2.1.1/1433 2.1.1/1433) and the Programme of Strategical Development of PetrSU (2012-2014).

\section{REFERENCES}

Fadeeva, M. A., Golubkova, N. S., Vitikainen, O. \& Ahti, T. 1997. Preliminary list of lichens and lichenicolous fungi of the Republic of Karelia. Petrozavodsk, 100 pp. (In Russian).

Fadeeva, M. A., Golubkova, N. S., Vitikainen, O. \& Ahti, T. 2007. Conspectus of lichens and lichenicolous fungi of the Republic of Karelia. Petrozavodsk, 194 pp. (In Russian).

Fagerström, L. 1945. En förteckning över lavar, insamlade i Fjärr-Karelen sensommaren 1942. Memoranda Societatis pro Fauna et Flora Fennica 20: $142-145$.

Koskinen, A. 1961. Floristische Beobachtungen über Flechten in Ostfennoskandien. Archivum Societatis Zoologicae Botanicae Fennicae "Vanamo" 15: 21-38. 
Kuzmina, I. G. \& Sonina, A. V. 2002. Comparative ecological analysis of epiphytic lichen cover in parks of Petrozavodsk and Pudoz cities. In: Proceedings of $3^{\text {rd }}$ International lichenological school and Congress "Boreal lichen flora. Lichenoindication". Ekaterinburg, pp. 45-46. (In Russian).

Lukashov, A. D. 2003. Geomorphological conditions. In: Diversity of Karelian biota: conditions, communities, species. Petrozavodsk, pp. 13-19. (In Russian).

Malysheva, N. V. 2005. Lichens of cities of European Russia. Abstract of thesis (prepared for the degree of doctor of biological sciences). Saint Petersburg, 38 pp. (In Russian).

Norrlin, J. P. 1876. Flora Kareliae Onegensis. II. Lichens. Meddelanden af Societas pro Fauna et Flora Fennica 1: 1-42.

Nylander, W. 1866 [preprint; 1882 in journal]. Lichenes Lapponiae orientalis. Notiser ur Sällskapets pro Fauna et Flora Fennica Förhandlingar 8(5): 101-192.

Red Data Book of Karelian Republic. 2007. Petrozavodsk, 368 pp. (In Russian).

Santesson, R., Moberg, R., Nordin, A., Tønsberg, T. \& Vitikainen, O. 2004. Lichen-forming and lichenicolous fungi of Fennoscandia. Uppsala, 359 pp. [Online version http:/ / 130.238.83.220/ santesson / find.php?-link=Find]

Sonina, A. V. \& Sysoyeva, M. I. 1997. Ecological features of litophile lichens of genera Porpidia. In: Proceedings of $6^{\text {th }}$ Youth Conference, Saint Petersburg, pp. 34. (In Russian).

Sonina, A. V., Novosjolov, D. V., Kornilov, P. S. \& Markovskaya, E. F. 2012. The epilithic lichens - indicators of coastal ecosystems in the conditions of pollution. In: Proceedings of $3^{\text {rd }}$ Congress of Russian Mycologists, vol. 3. Moscow, p. 253. (In Russian).

Sonina, A. V. Tarasova, V. N., Androsova, V. I., Shreders, M. A., Zvonilova, I. G., Volkova, N. V., Burma, S. S., Zinchenko, S. A., Rzaeva, K. V. \& Seljankina, A. A. 2008. Study of lichens in Petrozavodsk city (preliminary results). In: Proceeedings of Scientific
Conference "Flora and fauna in northern cities". Murmansk, pp. 23-26. (In Russian).

State report about environmental conditions of Karelian Republic. 2011. Petrozavodsk, 294 pp. (In Russian).

Svirko, E. V. 2006. Lichens - bioindicators of air pollution of Novosibirsk. Abstract of thesis (prepared for the degree of candidate of biological sciences). Novosibirsk, 16 pp. (In Russian).

Tarasova, V. N., Sysoyeva, M. I. \& Fadeeva, M. A. 1998. The role of environmental factors in distribution of epiphytic lichens in pine forest of Karelia. In: Proceedings of Inernational Scientific Conference "Karelia and Norway: the main trends and prospects of scientific cooperation". Petrozavodsk, pp. 54-57. (In Russian).

Tarasova, V. N. \& Evseeva, I. V. 2006. Long-term monitoring of Petrozavodsk using lichenoindication. In: Proceedings of International Scientific Conference "Northern Europe: nature, culture, economics". Petrozavodsk, pp. 214-216. (In Russian).

Tarasova, V. N. \& Sonina, A. V. 2006. Lichenological studies in the territory of Botanical Garden of PetrSU. Hortus Botanicus 4: 1-5. [http: / / hortus. karelia.ru/bgm/hb.htm] (In Russian).

Tarasova, V. N., Seljankina, A. A., Rzaeva, K. V. \& Shreders M. A. 2007. Lichenoindication of Petrozavodsk city: the first results. In: Proceedings of school-conference "Actual problems of geobotany".V. 2. Petrozavodsk, pp. 228-232. (In Russian).

Tarasova, V. N., Sonina, A. V. \& Androsova, V. I. 2010. Lichens. In: Plants and lichens of Petrozavodsk city (checklists). Petrozavodsk, pp. 158-174. (In Russian).

Tarasova, V. N., Sonina, A. V. \& Androsova, V. I. 2012. Lichens of Petrozavodsk: long-term changes of species diversity (period of 150 years). In: Proceedings of $3^{\text {rd }}$ Congress of Russian Mycologists, vol. 3. Moscow, p. 254. (In Russian).

Urbanavichus, G. 2010. A checklist of the lichen flora of Russia. Saint Petersburg, 194 pp. (In Russian). 